\title{
Single Phase Power Generation System from Fuel Cell
}

\author{
Nageswara Rao Kudithi, Sakda Somkun \\ School of Renewable Energy Technology, Naresuan University, Phitsanulok, Thailand
}

\begin{tabular}{|c|c|}
\hline Article Info & ABSTRACT \\
\hline Article history: & $\begin{array}{l}\text { Power conditioning circuits are required for the fuel cell systems due to its } \\
\text { nature in energetic state. This paper proposed the small signal average }\end{array}$ \\
\hline Received Jun 25, 2018 & modelling of a duel active bridge (DAB) DC-DC converter with LC filter, to \\
\hline Revised Sep 13, 2018 & generate the single phase AC power by using the H1000 fuel cell system. \\
\hline Accepted Sep 18, 2018 & $\begin{array}{l}\text { The controller is designed for the stable operation of the system. } \\
\text { Implemented the controller, which gives the constant output voltage to DC- }\end{array}$ \\
\hline Keyword: & $\begin{array}{l}\text { bus from the DAB DC-DC converter, this DC-bus voltage fed to the inverter, } \\
\text { which inverts the DC-bus voltage to single Phase AC power with the LC- }\end{array}$ \\
\hline DC-DC converters & imulated in the MATLAB/Simulink. \\
\hline
\end{tabular}

Fuel cell

Dual active bridge

Extended symmetric optimum

Copyright @ 2018 Institute of Advanced Engineering and Science. All rights reserved.

\section{Corresponding Author:}

Nageswara Rao Kudithi,

School of Renewable Energy Technology,

Naresuan University,

Phitsanulok, Thailand.

Email: nagnitw2006@gmail.com

\section{INTRODUCTION}

Nowadays, renewable energy sources has an important role in power generation area. It has many advantages and environmental friendly as well [1]. When we are using renewable energy sources we required an efficient power converters and storage elements. So recently power electronic converters plays an important role in energy distribution and storage [2]. In such systems, when storing and exploiting the energy, the power conditioning circuits are involved as an integral part of the system. Here the DC-DC converter acts as a power conditioning circuit. There are many topologies are proposed in the literatures, such as Non-Isolated and an Isolated with full-bridge and half-bridge topologies. Out of these, for the medium and high power applications where the voltage level transfer ratio is higher, the topologies without galvanic isolation are to be avoided in protection view point this motivates the DAB topology for this paper [3]-[5].

Renewable energy sources such as Fuel-Cells, Photo-Voltaic (PV) arrays are increasingly being used in automobiles, residential and commercial buildings [6]. Fuel cells are emerging technology and the most promising sources of standalone system applications as small as cell phones to as large as utility power generation, with high efficiency because of direct energy conversion, scalability and low environmental impact [7]. It is fit for generating electrical energy without global warming, but unfortunately some of the complications are occurred due to its slow response in the dynamic operation. Fuel cells are cannot accept reverse direction currents like a battery, do not respond well for ripple current, it's have low output voltage that differs with current and life time, it's do not have capability to respond quickly for load changes and manage specified load [8].

So fuel cells are required productive energy transfer system with low power losses. This paper the Switched mode DC-DC Converters are used for boost fuel cell voltage for required single phase power loads like grid, electric vehicles and AC motors. Switched mode converters are working within the soft switching regain and with high frequency transformer, high power density, high efficiency, zero voltage switching, 
bidirectional power flow, and galvanic isolation which is fulfil the low voltage fuel cell power generation system requirements, the topology illustrate in Figure 1 to minimize the overall losses of system, where the futures of zero voltage switching (ZVS) capability, bidirectional power flow and high frequency transformer for galvanic isolation is adapted [9]-[11]. This feature provides the effective conversion of power, small volume and low weight construction. In addition, small signal model for the system, the related control design of the converter and open loop system with resistive and inductive load inverter are developed and also which reduce the cost of the system as well [12].

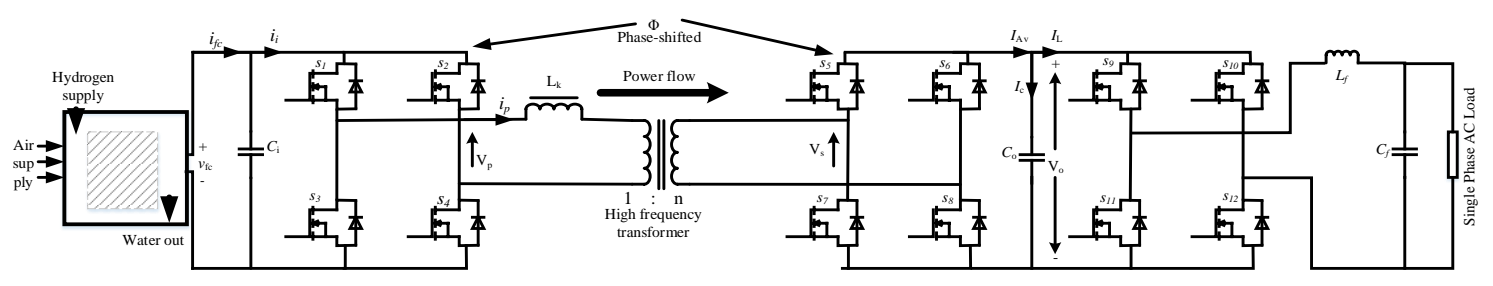

Figure 1. Single phase power generation circuit with fuel cell

\section{CIRCUIT DESCRIPTION}

Fuel cell systems are generally rated with the power range of $10 \mathrm{~W}-5 \mathrm{~kW}$ with the voltage ranges $7.8 \mathrm{~V}-72 \mathrm{~V}$. Three phase of operational regions were in fuel cell which are activation, Ohmic, and concertation as shown in the polarization curve [13]. The operating point should choose in the Ohmic region from the data sheet of fuel cell to extend the life time. In critical applications such as a single phase AC power generation system with DC-DC converters.

Fuel cell system is connected with two full bridge isolated DC-DC converters as shown in Figure 1, which are connected with high frequency transformer $\left(\mathrm{T}_{\mathrm{f}}\right)$ and extremal small leakage inductor $\left(\mathrm{L}_{\mathrm{lk}}\right)$, the electrolytic capacitor $\left(\mathrm{C}_{\mathrm{i}}\right)$ as the energy buffer in the primary H-bridge (port-1), to reduce the low frequency current ripple in the input side connected to DC-bus voltage $(\mathrm{Vdc})$ which is connected to a single phase voltage source inverter for the conversion of the DC-AC for the AC loads or Grid connection. In this circuit energy transfer occurs due to the phase shift between the two H-bridges, phase shift $(\phi)$ modulation is employed to proceed the power from input port- 1 to output port-2 is determined by phase angle $(\phi)$ between the primary winding and secondary winding voltages of the transformer(Tf), that is given the power flow expression as [14].

$$
\mathrm{P}_{\mathrm{FC}}=\frac{\mathrm{V}_{\mathrm{FC}}^{2} \mathrm{~d} \emptyset}{\pi \mathrm{wL} \mathrm{L}_{\mathrm{k}}}(\pi-\varnothing)
$$

where

$\mathrm{V}_{\mathrm{FC}}$ - is the fuel cell DC output voltage

d - is the voltage transfer ratio referred to primary,

$\mathrm{L}_{\mathrm{lk}} \quad$ - is the leakage inductance of the transformer,

$\Phi \quad$ - is the phase shift between the bridge gate signals.

$\mathrm{DC}$ voltage must be $\sqrt{2}$ times of the peak value $\mathrm{AC}$ voltage required. So the voltage conversion ratio is very high for the medium and high power requirements where the need of isolated DC-DC converter is essential to meet the required voltage level and conventional boost converters cannot be used in such cases. The dual active bridge DC-DC converters which were originally proposed with soft switching is a better topology among others for fuel cell applications.

\section{MODALING OF THE SYSTEM}

In the literature so many PEM fuel cell models are reported based in the thermodynamic and electrochemical expressions. The fuel cell model considered with constant hydrogen pressure flow into the fuel cell stacks for dynamic operation. Fuel cell output voltage is expressed as [15].

$$
\mathrm{V}_{\mathrm{fc}}=\mathrm{E}-\mathrm{V}_{\mathrm{act}}-\mathrm{V}_{\text {conc }}-\mathrm{V}_{\mathrm{ohm}}
$$

where

$\mathrm{E} \quad-$ is open circuit fuel cell voltage $\left(\mathrm{V}_{\mathrm{oc}}\right)$ 
$\mathrm{V}_{\text {act }} \quad$ - is activation voltage losses at zero current density $\left(\mathrm{I}_{\mathrm{o}}\right)$

$\mathrm{V}_{\text {conc }}-$ is voltage drop due to concentration losses in fuel input

$\mathrm{V}_{\mathrm{ohm}} \quad$ - is voltage drop of Ohmic losses

From the above expression (2) and based on the polarization cure has been observed that a fuel cell can operated with the linear region while changing the constant internal resistance with respective of output loads. So based on this observation it can be linearized by using the expression below (3),

$$
\mathrm{V}_{\mathrm{fc}}=\mathrm{E}-\mathrm{R}_{\mathrm{fc}} \mathrm{I}_{\mathrm{fc}}
$$

where

$\mathrm{R}_{\mathrm{fc}} \quad$ - is linearized resistance

$\mathrm{I}_{\mathrm{fc}} \quad$ - is fuel cell current

So its gives the dynamic operation region of the fuel cell between the lower and upper current limits.

The DC voltage from the fuel cell is converted into a high frequency square wave AC voltage(nonsinusoidal) at the primary winding side of the transformer by the H-bridge of port-1. The converted AC voltage is stepped up to high voltage square wave(non-sinusoidal) at secondary winding of the transformer by the H-bridge of port- 2 with a desired phase shift to meet the required load power. The output of the $\mathrm{H}$ bridge of Port-2 is a high DC voltage.

As shown in Figure 2 waveforms of the voltage, currents in primary winding and secondary windings of the transformer. The instantaneous value of the primary current at any given instant of ' $\theta$ ' as follows the expressions are,

$$
i(\theta)=\left\{\begin{array}{cr}
i(0)+\left(\frac{V_{\mathrm{i}}+\mathrm{V}_{\mathrm{o}}}{w L}\right) \theta, & 0<w \mathrm{t}<\varnothing \\
\mathrm{i}(\varnothing)+\left(\frac{\mathrm{V}_{\mathrm{i}}-\mathrm{V}_{\mathrm{o}}}{w \mathrm{~L}}\right)(\theta-\varnothing), & \varnothing<w \mathrm{t}<\pi
\end{array}\right.
$$

The expression (4) can be deduced to get the values of the current $\left(i_{p}\right)$ in the primary side of the transformer expressed as,

$$
\left.\begin{array}{l}
\mathrm{i}_{\mathrm{P}}(0)=-\frac{\mathrm{V}_{\mathrm{fc}}}{\mathrm{wL}_{\mathrm{lk}}}\left[\mathrm{d} \emptyset-\frac{\pi^{*}(1-\mathrm{d})}{2}\right] \\
\mathrm{i}_{\mathrm{P}}(\varnothing)=\frac{\mathrm{V}_{\mathrm{fc}}}{\mathrm{wL}_{\mathrm{lk}}}\left[\varnothing+\frac{\pi^{*}(1-\mathrm{d})}{2}\right]
\end{array}\right\}
$$

Where the first zero crossing point ( $y$ ) of $i_{p}$ form Figure 2 is given as

$$
\mathrm{y}=\frac{2 \mathrm{~d} \emptyset+\pi(1-\mathrm{d})}{2(1+\mathrm{d})}
$$

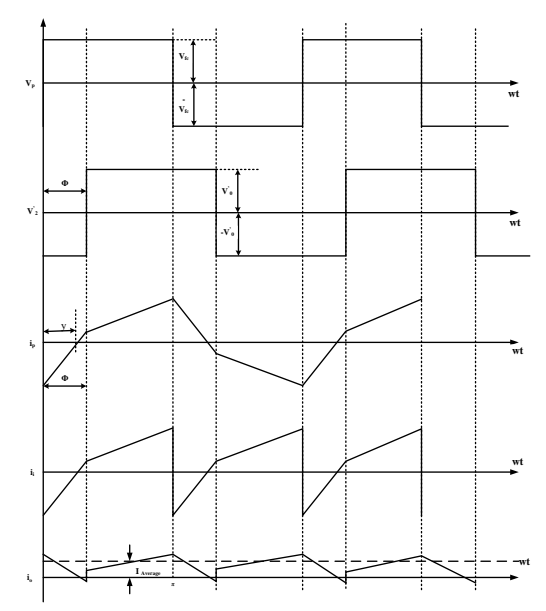

Figure 2. Voltage and Current Waveforms 
The boundary conditions [16] of the H-bridge in the primary winding side voltage(LV) and $\mathrm{H}$ bridge in the secondary winding side voltage $(\mathrm{HV})$ for Zero voltage switching $(Z V S)$ are found to be $\mathrm{i}_{\mathrm{p}}(0)<0$ and $i_{p}(\phi)>0$ respectively. This can be found by substituting $i_{p}(0)=0$ and $i_{p}(\phi)=0$, which will ensure a negative current in the LV H-bridge through the diodes clamping the voltage across the switches to be the negligible forward voltage drop across them enabling almost zero voltage at the time of turn ON. Similarly, a positive current in the HV H-bridge makes the diodes conduction ensuring almost zero voltage across the switches at the time of turn ON. During the turn OFF process, the capacitors across the switches store the ON state voltage and enables the ZVS at the time of turn OFF. Which will greatly reduce the switching losses and hence increase the efficiency.

Average power transferred to the load from the fuel cell is expressed below as,

$$
\mathrm{P}_{\mathrm{FC}}=\mathrm{V}_{\mathrm{FC}} \mathrm{I}_{\mathrm{Ave}}
$$

Where $\mathrm{I}_{\mathrm{ave}}=\frac{\mathrm{V}_{\mathrm{FC}} \mathrm{d} \emptyset(\pi-\varnothing)}{\pi \mathrm{wL} / \mathrm{k}}$ from the expressions of (1), (4) and (5).

Because of the half wave symmetry of the wave form shown in Figure 2. It gives the average power transfer expression as below

$$
\mathrm{P}_{\mathrm{FC}}=\mathrm{V}_{\mathrm{FC}}^{2} \frac{\mathrm{d} \emptyset(\pi-\varnothing)}{\pi \mathrm{wL} / \mathrm{k}}
$$

Hence the average current can be used for modelling of the DAB, which is a non-linear function of the phase shift $\phi$ as given below

$$
\mathrm{I}_{\mathrm{ave}}=\frac{\mathrm{V}_{\mathrm{FC}} \mathrm{d} \emptyset}{\mathrm{wL}_{\mathrm{lk}}} \mathrm{K}_{\varnothing}
$$

Where $\quad \mathrm{K}_{\varnothing}=\frac{(\pi-\varnothing)}{\pi}$ the system as

The averaged model of the DAB is shown in Figure 3 which gives the open loop transfer function of

$$
\mathrm{G}_{\mathrm{DAB}}(\mathrm{s})=\frac{\mathrm{K}_{\emptyset}}{\mathrm{C}_{0}} \frac{1}{\mathrm{~s}}
$$
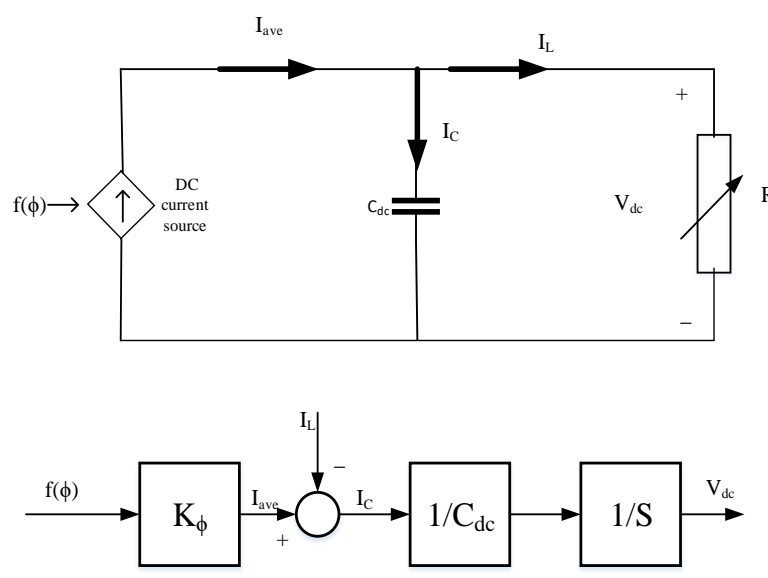

Figure 3. modeling circuits of DAB

\section{INVERTER WITH LC-FILTER}

The DAB converse low DC-voltage to a high DC-voltage from the fuel cell in order to AC voltage as a part of multistage power converter topology. A switched mode DC-AC inverter is considered for grid or AC load connected fuel cell systems. The magnitude and the frequency of the sinusoidal AC output can be controlled in these inverters. The output of this inverter must be matched with the magnitude, frequency and phase of the specified AC load or grid voltage, which is achievable in this switched mode inverter. 
The high frequency switching of the pulse width modulation (PWM) inverter results from a nonsinusoidal voltage at the output with high frequency distortions. These non-sinusoidal voltages cause the current to be highly distorted when connected to the load or the grid. An LC-filter made up of inductor $\mathrm{L}_{\mathrm{f}}$ in series with the load and capacitor $\mathrm{C}_{\mathrm{f}}$ parallel to the load. It's possess the advantages of the L-filter and Cfilter. Aside from this ripple factor in LC- filter is lower value than that acquire by either one of the both filters ( $\mathrm{L}$ or $\mathrm{C}$ ) for the same values. Figure 4 shows the use of the LC-filter for minimizing the ripple from the voltage of a single-phase inverter output. The dominant harmonics are suppress by the filter inductor $\left(\mathrm{L}_{\mathrm{F}}\right)$ and the Capacitor $\left(C_{f}\right)$ provides a simple way to the harmonic ripple currents [17]-[19].

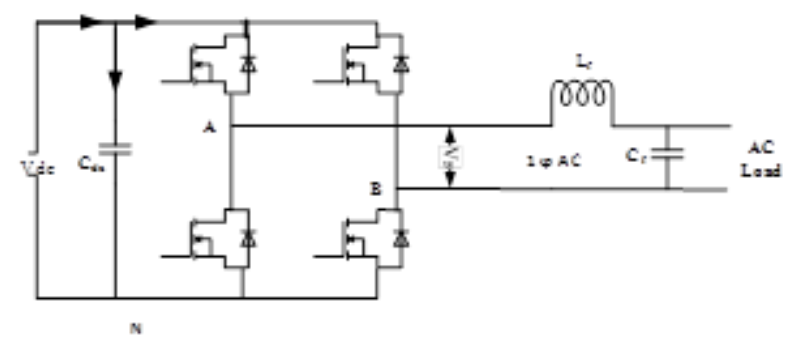

Figure 4. single phase full bridge inverter with LC-filter

Inductance value $\left(\mathrm{L}_{\mathrm{f}}\right)$ of the filter is computed such that the voltage drop in the inductor is not more than $3 \%$ to $5 \%$ of the inverter output voltage $\mathrm{V}_{\mathrm{o}}$.

$$
\left.\begin{array}{c}
2 \pi \mathrm{f}_{\mathrm{o}} \mathrm{L}_{\mathrm{f}} \mathrm{I}_{\mathrm{Lmax}}<0.03 * \mathrm{~V}_{\mathrm{o}} \\
\mathrm{L}_{\mathrm{f}}<\frac{0.03 * \mathrm{~V}_{\mathrm{o}}}{2 \pi \mathrm{f}_{\mathrm{o}} \mathrm{I}_{\mathrm{Lmax}}}
\end{array}\right\}
$$

Where

$\mathrm{f}_{\mathrm{o}} \quad$-is output frequency of the L-C filter $50 \mathrm{~Hz}$,

$\mathrm{L}_{\mathrm{f}} \quad$ - is inductance of filter,

$\mathrm{I}_{\mathrm{Lmax}}$-is maximum RMS (root mean square) of load current,

$\mathrm{V}_{\mathrm{o}} \quad$-is the output voltage RMS value.

Capacitance value $\left(\mathrm{C}_{\mathrm{f}}\right)$ of the filter is computed with the help of resonance relation as,

$$
\mathrm{C}_{\mathrm{f}}=\frac{1}{\left(2 \pi \mathrm{f}_{\mathrm{r}}\right)^{2} \mathrm{~L}_{\mathrm{f}}}
$$

Where $f_{r}$ - is cut-off frequency of LC-filter.

\section{DESIGN OF THE PI-CONTROLLER}

Now single phase inverter is considered to be as the load, it should be chosen so as to limit the bandwidth below the double line frequency of the load, which allows a double line frequency ripple in the voltage of the DC-bus. A low pass filter is introduced to limit the frequency of the ripple current extracted from fuel cell. The time constant $\mathrm{T}_{\mathrm{f}}$ of the low pass filter is chosen to limit in only a DC current extract from the fuel cell, which is good for the fuel cell membrane.

PI-controller is considered in the system for the stability in the voltage of the DC-bus under the desired set point and disturbance variations as shown in the Figure 5. In this design an extended symmetrical optimum method (ESOM) [20] is used in the tuning of the controller. The gain of the open loop system is given below as

$$
\mathrm{G}_{\mathrm{OL}}(\mathrm{s})=\frac{\mathrm{K}_{\mathrm{p}} \mathrm{K}_{\mathrm{c}}\left(1+\mathrm{T}_{\mathrm{c}} \mathrm{s}\right)}{\mathrm{s}^{2}\left(1+\mathrm{T}_{\mathrm{F}} \mathrm{s}\right)}
$$




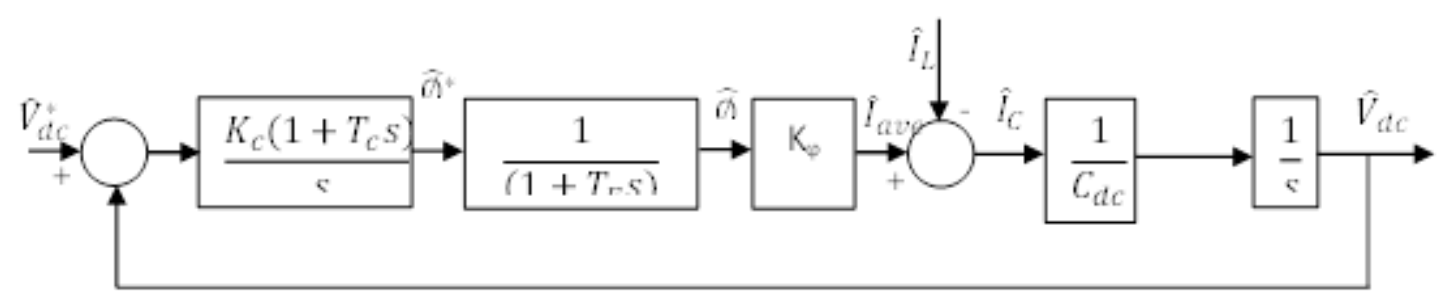

Figure 5. DC link voltage loop control

The system derive from a variable gain process in which $\mathrm{K}_{\emptyset}=\frac{(\pi-\emptyset)}{\pi}$ is a variant. Hence the ESOM is suitable for this type of plant with variable parameter $\mathrm{Kp}$ chosen to compute the parameters of the PI controller. It provides the values of parameters $\mathrm{Kc}$ and $\mathrm{Tc}$ at the median of $\mathrm{K}_{\phi}$, so that maximum phase margin is ensured at the given crossover frequency $\left(\mathrm{w}_{\mathrm{c}}\right)$ even if $\mathrm{K}_{\phi}$ is disparate.

From the ESOM, PI controller Parameters $\mathrm{K}_{\mathrm{c}}$ and $\mathrm{T}_{\mathrm{c}}$ as

$$
\left.\begin{array}{c}
\mathrm{K}_{\mathrm{p}} \mathrm{K}_{\mathrm{c}}=\frac{1}{\beta \sqrt{\beta} \mathrm{T}_{\mathrm{F}}^{2}} \quad \text { and } \\
\mathrm{T}_{\mathrm{c}}=\beta \mathrm{T}_{\mathrm{F}}
\end{array}\right\}
$$

Where $\beta$ - is a parameter chosen between 4 and 16 based on required system performance [20] such as rise time, peak overshoot, and settling time. When $\beta<4$ the phase margin $\emptyset_{r M}<36^{\circ}$ which is too small and when $\beta>16$ the phase margin $\emptyset_{r M}>60^{\circ}$ where such high values are not necessary. In this simulation the parameter $\beta$ is chosen as 6 for a maximum phase margin of $45^{\circ}$ of the open-loop system.

The open-loop(OL) and closed loop(CL) bode diagrams are as shown in the Figure 6(a) and (b). It can found that the maximum phase margin of $45.6^{\circ}$ is given by the controller at $25 \mathrm{~Hz}$ with the low-pass filter.

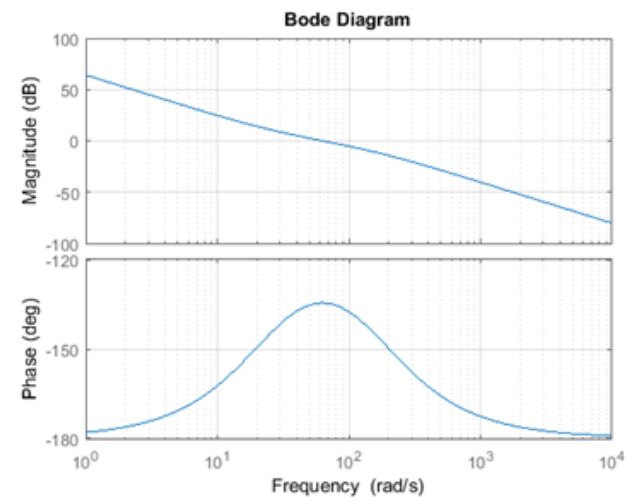

(a)

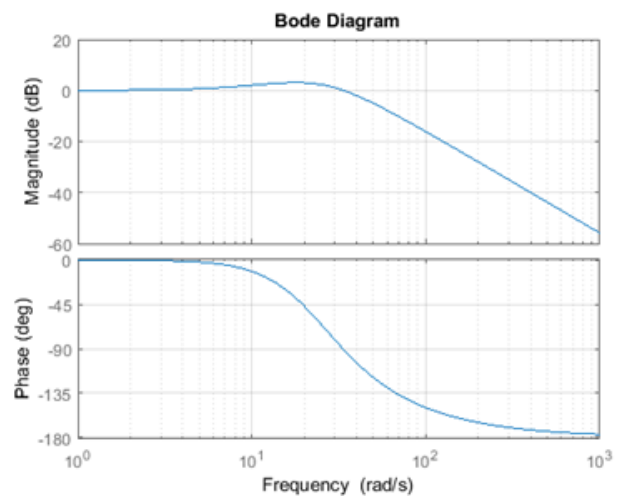

(b)

Figure 6. (a) Bode-diagram of the OL system; (b) Bode-diagram of the CL system

From the expressions (13) and (14) the optimal closed loop gain of the entire system is

$$
\mathrm{G}_{\mathrm{CL}}(\mathrm{s})=\frac{\beta \mathrm{T}_{\mathrm{F}} \mathrm{s}+1}{\beta \sqrt{\beta} \mathrm{T}_{\mathrm{F}}^{3} \mathrm{~s}^{3}+\beta \sqrt{\beta} \mathrm{T}_{\mathrm{F}}^{2} \mathrm{~s}^{2}+\beta \mathrm{T}_{\mathrm{F}} \mathrm{s}+1}
$$

The cut-off frequency $w_{c}$ of the DC-bus voltage control loop is selected for the low pass filter

$$
\mathrm{w}_{\mathrm{c}}=1 / \sqrt{ } \beta \mathrm{T}_{\mathrm{F}}
$$


The cut off frequency $\mathrm{w}_{\mathrm{c}}$ is choose as $25 \mathrm{~Hz}$. The phase margin is $89^{\circ}$ at $32.9 \mathrm{~Hz}$ of the closed loop system from the bode diagram as shown in the Figure 6(b). This ensures that stable operation of the system within the double line frequency of the inverter load with the safe range of ripple current in the fuel cell.

\section{SIMULATION RESULT}

Simulation of the model is done with MATLAB/Simulink by using the power system block sets connected to the two H-bridges with a high frequency transformer for different loads. The constant DC voltage source was chosen with $0.333 \mathrm{ohm}$ resistance, which is equal to the dynamic resistance of a $1 \mathrm{~kW}$ Horizon fuel cell. The simulation was done in two parts, the first part without inverter only resistive loads. The simulation results are shown in Figure 7 for load voltage $\left(V_{o}\right)$ and load current $\left(I_{0}\right)$ with respect to the load changes, input voltage (Vi) and input current (Ii) as the load differs from $200 \mathrm{~W}$ to $1000 \mathrm{~W}$ and to $400 \mathrm{~W}$. The maximum ripple in the input current (Ii) is occurred 2A when it is connected to full load $1000 \mathrm{~W}$, it is safe range for fuel cell. Table 1 gives the simulation parameters.
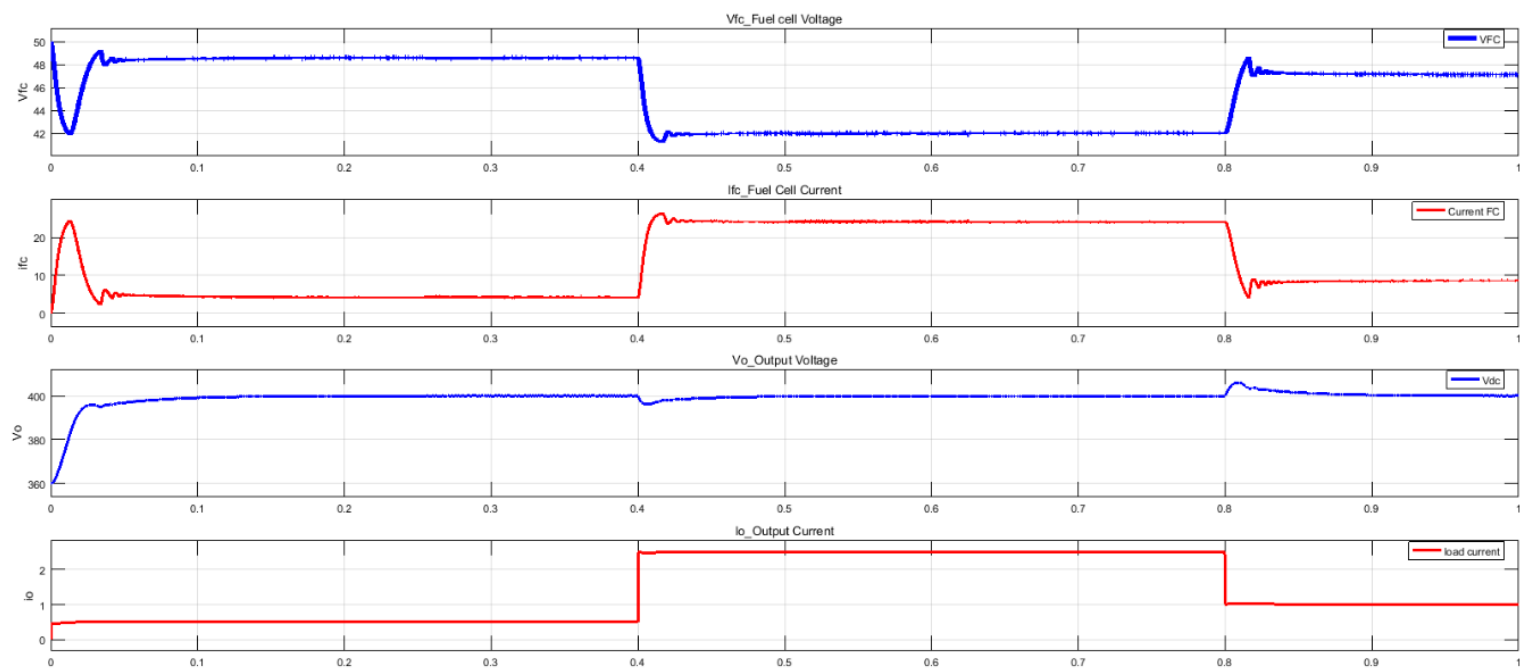

Figure 7. input and output voltage and currents for load $200 \mathrm{~W}$ to $1000 \mathrm{~W}$ and to $400 \mathrm{~W}$

Table 1. Parameters and respective values

\begin{tabular}{llll}
\hline \multicolumn{1}{c}{$\mathrm{DAB}$} & \multicolumn{1}{c}{ Inverter } \\
\hline Input voltage, $\mathrm{V}_{\mathrm{fc}}$ & $50 \mathrm{~V}$ & Input voltage, $\mathrm{V}_{\mathrm{s}}$ & $400 \mathrm{~V}$ \\
Internal resistance, $\mathrm{Rfc}$ & $0.333 \mathrm{ohm}$ & Output voltage, $(\mathrm{RMS}) \mathrm{V}_{\mathrm{o}}$ & $220 \mathrm{~V}$ \\
Input capacitance, $\mathrm{Ci}$ & $4700 \mu \mathrm{F}$ & Filter indactance, $\mathrm{L}_{\mathrm{f}}$ & $0.051 \mu \mathrm{H}$ \\
Output voltage, $\mathrm{V}_{\mathrm{o}}$ & $400 \mathrm{~V}$ & Switching freqency(inverter), $\mathrm{f}_{\text {sinv }}$ & $10 \mathrm{kHz}$ \\
Output capacitance, $\mathrm{C}_{\mathrm{o}}$ & $1000 \mu \mathrm{F}$ & Cut-off frequency, $\mathrm{f}_{\mathrm{r}}$ & $3 \mathrm{kHz}$ \\
Maximum output power, $\mathrm{P}_{\mathrm{o}}$ & $1000 \mathrm{~W}$ & Output frequency, $\mathrm{f}_{\mathrm{o}}$ & $50 \mathrm{~Hz}$ \\
Switching freqency $(\mathrm{DAB}), \mathrm{f}_{\mathrm{s}}$ & $20 \mathrm{kHz}$ & Output capacitance, $\mathrm{C}_{\mathrm{f}}$ & $0.548 \mu \mathrm{F}$ \\
Leakage indactance, $\mathrm{L}_{\mathrm{lk}}$ & $11.71 \mu \mathrm{H}$ & & \\
\hline
\end{tabular}

The second part of the simulation result is shown in Figure 8 (a) and (b). are the fuel cell voltage and current with inverter input voltage $\left(\mathrm{V}_{\mathrm{dc}}\right)$, inverter output voltage $(\mathrm{Vs})$, inductor current $\left(\mathrm{i}_{\mathrm{L}}\right)$, output voltage of LC-filter $\left(\mathrm{V}_{\mathrm{o}}\right)$, and output current $\left(\mathrm{I}_{\mathrm{o}}\right)$ for R, and RL load with unipolar PWM controller. 


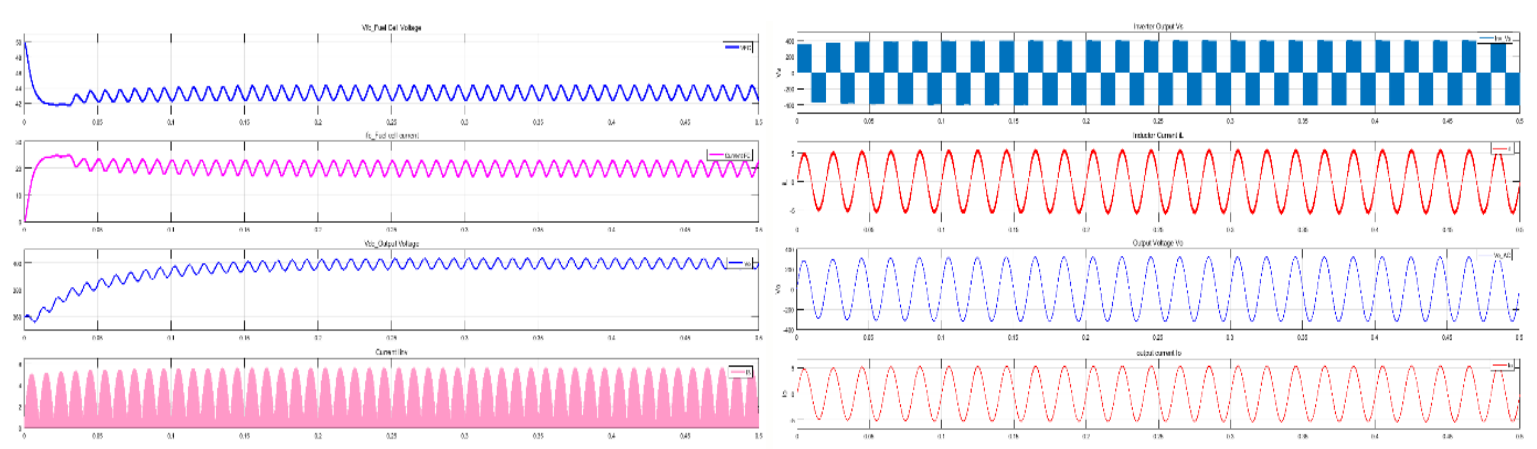

Figure 8(a). Result of inverter with LC-filter outputs for R-Load
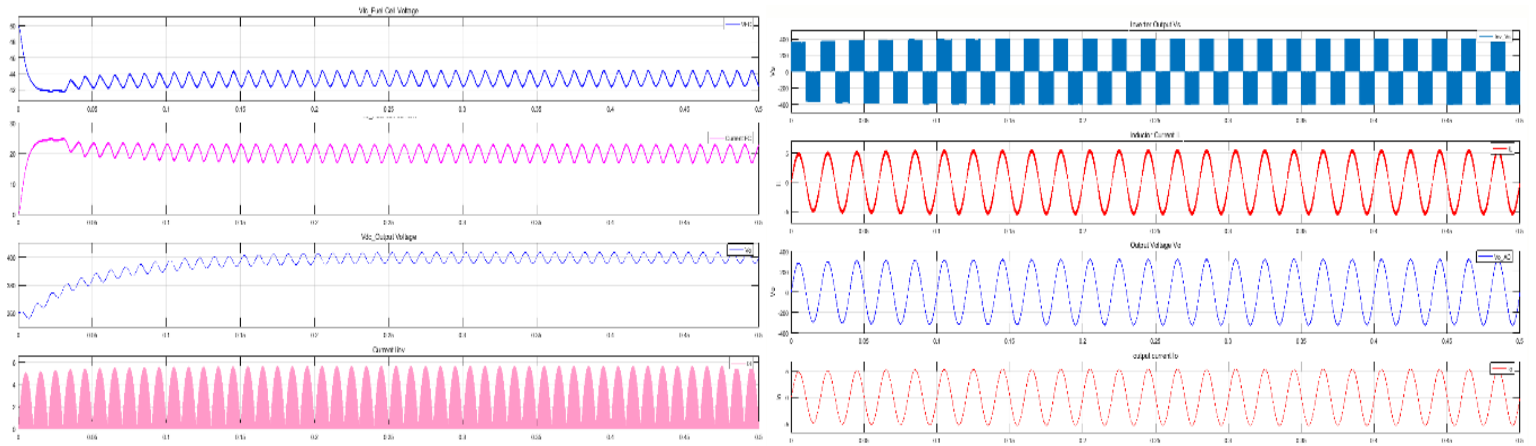

Figure 8(b). Result of inverter with LC-filter outputs for RL-Load

\section{CONCLUSION}

Dual active bridge DC-DC converter considered as single phase generation system for fuel cell applications and average small signal model has been developed for it. Simulations are done by using MATLAB/Simulink power system block sets. A PI controller has been proposed and developed for system stability under the desired output and varies loads using ESOM with DC load variations of 200W to $1000 \mathrm{~W}$ and $400 \mathrm{~W}$ as shown in Figure 7.

Implemented the LC-filter with the DAB to get the sinusoidal voltage as shown in Figures 8 (a) and (b) for different loads by choosing high resistance and low inductance in the AC load to get the maximum power output. This system design can be used for the implication of three port bidirectional dc-dc converter of fuel cell application and use it as single phase AC power generation.

\section{REFERENCES}

[1] Dudley B., "BP statistical review of world energy 2015," London, UK, 2015.

[2] Blaabjerg F., et al., "Power electronics as efficient interface in dispersed power generation systems," IEEE Transactions on Power Electronics, vol. 19, pp. 1184-94, 2004.

[3] Goh H. H., et al., "Predictive Direct Power Control (PDPC) of Grid-connected Dual-active Bridge Multilevel Inverter (DABMI)," International Journal of Power Electronics and Drive Systems (IJPEDS), vol. 8, pp. 1524-33, 2017.

[4] Zgheib R. and Kamwa I., "Comparison between isolated and non-isolated DC-DC converters for bidirectional EV chargers," 2017 IEEE International Conference on Industrial Technology (ICIT), pp. 515-20, 2017.

[5] Zhao B., et al., "Overview of Dual-Active-Bridge Isolated Bidirectional DC-DC Converter for High-FrequencyLink Power-Conversion System," IEEE Transactions on Power Electronics, vol. 29, pp. 4091-106, 2014.

[6] Athikkal S., et al., "A modified dual input DC-DC converter for Hybrid Energy Application," International Journal of Power Electronics and Drive Systems (IJPEDS), vol. 8, pp. 81-92, 2017.

[7] Jafri N. H. and Gupta S., "An overview of Fuel Cells application in transportation," 2016 IEEE Transportation Electrification Conference and Expo, Asia-Pacific (ITEC Asia-Pacific), pp. 129-33, 2016.

[8] Ali D. M. and Salman S., "A comprehensive review of the fuel cells technology and hydrogen economy," Universities Power Engineering Conference, 2006 UPEC'06 Proceedings of the 41st International: IEEE, pp. 98102, 2006. 
[9] Prasetya T., et al., "Design of Full-bridge DC-DC Converter 311-100 V 1kW with PSPWM Method to Get ZVS Condition," International Journal of Power Electronics and Drive Systems (IJPEDS), vol. 8, pp. 59-68, 2017.

[10] Xue L., et al., "Dual active bridge-based battery charger for plug-in hybrid electric vehicle with charging current containing low frequency ripple," IEEE Transactions on Power Electronics, vol. 30, pp. 7299-307, 2015.

[11] Shah S. S. and Bhattacharya S., "Large \& small signal modeling of dual active bridge converter using improved first harmonic approximation," Applied Power Electronics Conference and Exposition, IEEE, pp. 1175-82, 2017.

[12] Tao H., et al., "Transformer-coupled multiport ZVS bidirectional DC-DC converter with wide input range," IEEE Transactions on Power Electronics, vol. 23, pp. 771-81, 2008.

[13] James L. and Andrew D., "Fuel cell systems explained," Chichster, John Wiley \& Sons Ltd., 2003.

[14] Doncker R. W. A. A. D., et al., "A three-phase soft-switched high-power-density DC/DC converter for high-power applications," IEEE Transactions on Industry Applications, vol. 27, pp. 63-73, 1991.

[15] Tremblay O. and Dessaint L. A., "A generic fuel cell model for the simulation of fuel cell vehicles," Vehicle Power and Propulsion Conference, IEEE, pp. 1722-9, 2009.

[16] Azri M., et al., "Fuel Cell Emulator with MPPT Technique and Boost Converter," International Journal of Power Electronics and Drive Systems (IJPEDS), vol. 8, pp. 1852-62, 2017.

[17] Bimbhra P. and Kaur S., "Power electronics," Khanna publishers, 2012.

[18] Tali M., et al., "Passive filter for harmonics mitigation in standalone PV system for non linear load," Renewable and Sustainable Energy Conference (IRSEC), 2014 International: IEEE, pp. 499-504, 2014.

[19] Teryima K. D., et al., "A Overlapping Carrier Based SPWM for a 5-Level Cascaded H-bridge Multilevel Inverter," International Journal of Power Electronics and Drive Systems (IJPEDS), vol. 7, pp. 349-57, 2016.

[20] Preitl S. and Precup R. E., "Technical Communique: An extension of tuning relations after symmetrical optimum method for PI and PID controllers," Automatica (Journal of IFAC), vol. 35, pp. 1731-6, 1999. 